\title{
Assessing the human immune system through blood transcriptomics
}

\author{
Damien Chaussabel*, Virginia Pascual and Jacques Banchereau
}

\begin{abstract}
Blood is the pipeline of the immune system. Assessing changes in transcript abundance in blood on a genome-wide scale affords a comprehensive view of the status of the immune system in health and disease. This review summarizes the work that has used this approach to identify therapeutic targets and biomarker signatures in the field of autoimmunity and infectious disease. Recent technological and methodological advances that will carry the blood transcriptome research field forward are also discussed.
\end{abstract}

\section{Profiling the human immune system}

The immune system plays a central role not only in health maintenance but also in pathogenesis: excess immunity is associated, for instance, with auto-immune diseases (for example, multiple sclerosis, type 1 diabetes, psoriasis, lupus, rheumatoid arthritis), inflammation (sepsis, inflammatory bowel disease) and allergy, as well as cell and organ rejection; deficient immunity is, on the other hand, linked to cancer or susceptibility to infection.

When investigating immune-mediated diseases in humans, restricted access to relevant tissue(s) for sampling, such as the brain in multiple sclerosis or the joints in rheumatoid arthritis, constitutes a major limitation. Cells of the immune system, however, become educated and implement their functions by recirculating between central and peripheral lymphoid organs as well as by migrating to and from sites of injury via the blood (Figure 1). As blood flows throughout the body, carrying naïve and educated immune cells from one site to another, it acts as a pipeline for the immune system. Indeed, it is the preferred route for immune cells to reach the lymph nodes where antigen-specific immune responses develop. After exiting these nodes through

*Correspondence: DamienC@BaylorHealth.edu Baylor Institute for Immunology Research and Baylor Research Institute, 3434 Live Oak, Dallas, TX 75204, USA outgoing lymphatic vessels, the cells again reach the bloodstream to be transported to tissues throughout the body. Upon patrolling these tissues, they gradually drift back into the lymphatic system to re-enter the blood and begin the cycle all over again. The complex patterns of recirculation depend on the state of cell activation, the adhesion molecules expressed by immune and endothelial cells, and the presence of chemotactic molecules that selectively attract particular populations of blood cells. Circulating immune cells are, in addition, exposed to factors that are released systemically.

A wide range of molecular and cellular profiling assays is currently available for the study of the human immune system (Figure 2). The level of sophistication of instruments such as polychromatic flow cytometers, one of the immunologist's favorite tools, has increased over the past few years. Major technological breakthroughs have also occurred in the fields of genomics and proteomics, thus creating today a unique opportunity for the study of human beings in health and disease where inherent heterogeneity dictates that large collections of samples be analyzed. Among the high-throughput molecular profiling technologies available today, genomic approaches are the most scalable, have the most breadth and robustness, and therefore are best suited for the study of human populations.

The human genome can be investigated from two different angles that consist of either determining its make up or measuring its output. Sequence variation can be detected using, for instance, single nucleotide polymorphism (SNP) chips, which permit the identification of common polymorphisms or rare mutations associated with diseases. Hundreds of thousands of SNPs can be typed using these platforms, yielding a genome-wide, hypothesis-free scan of genetic associations for a given phenotype of interest. Many such genome-wide association studies (often referred to as GWAS) have been published in recent years, a number of them investigating the genetic underpinning of immune-related diseases [1]. Notably, such studies have been useful to pinpoint genes and pathways that may be involved in the pathogenesis of 


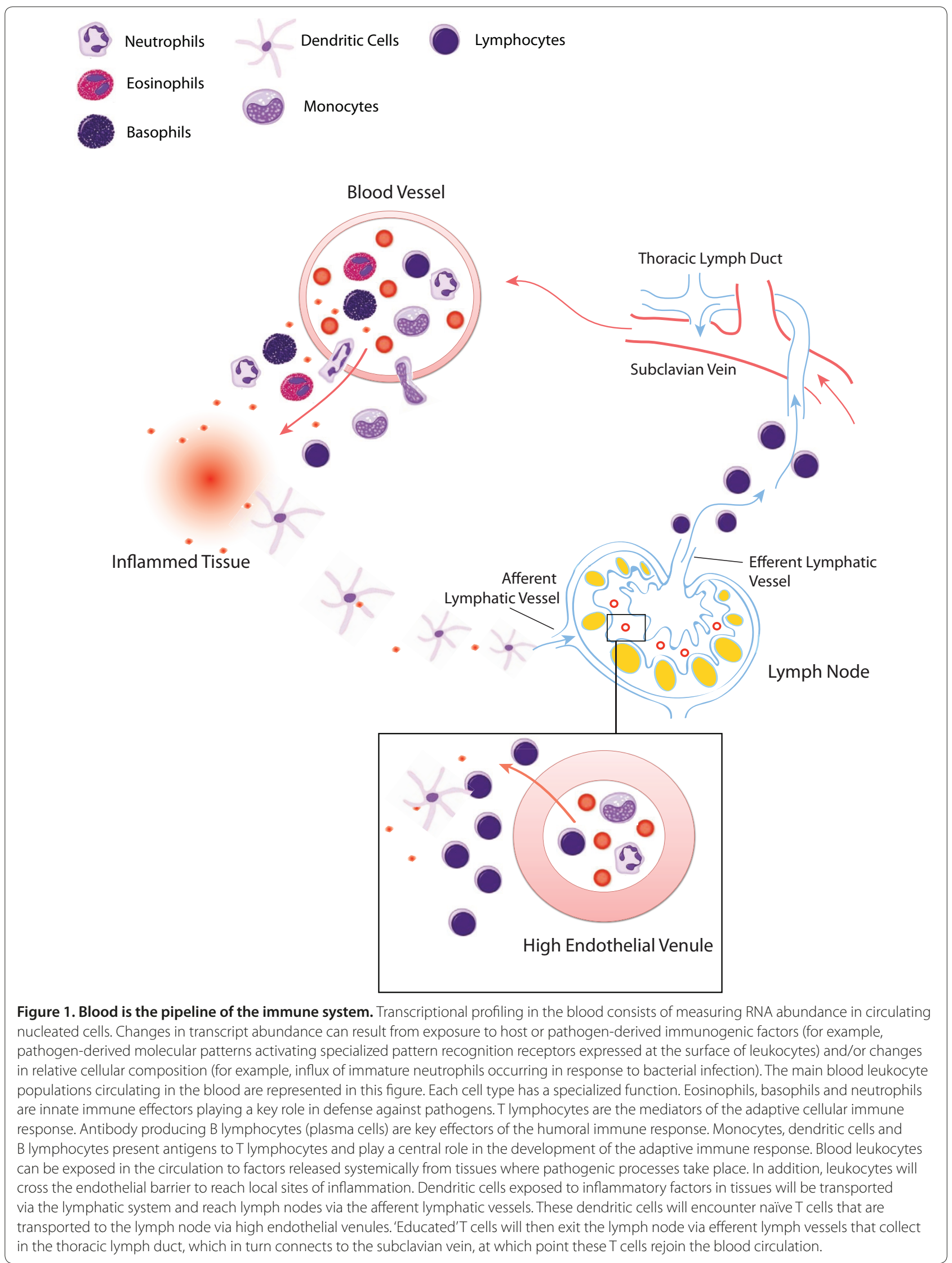




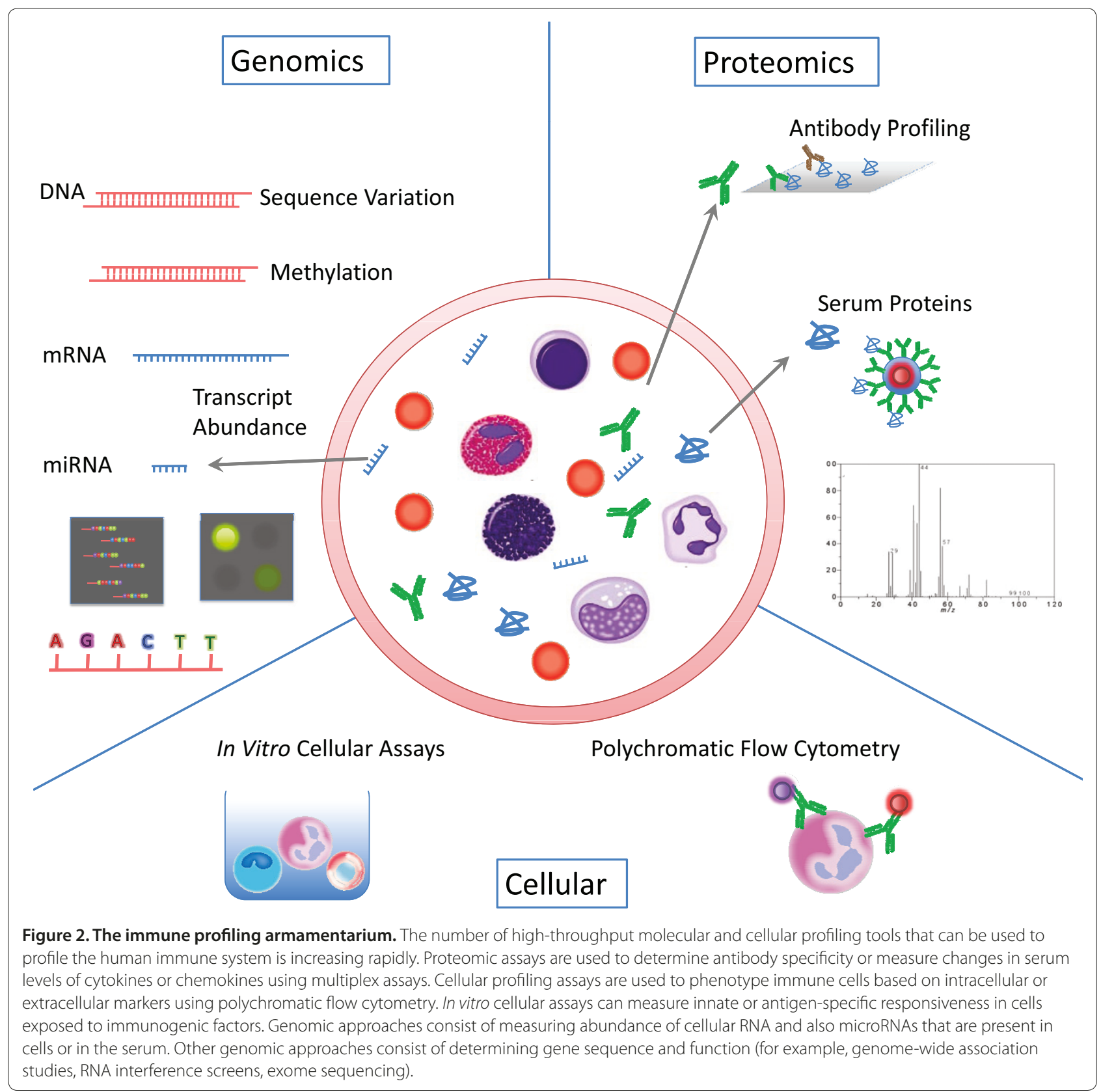

autoimmune diseases [2]. Associations between common genetic variants and resistance to infection have also been reported $[3,4]$. However, parameters measured by this approach are determined by heredity and will not change throughout the life of an individual. This is in contrast to transcript abundance, which is the parameter measured by the second genome-wide profiling approach. Transcriptional activity is largely dependent on environmental factors and, as a result, RNA abundance will change dynamically over time. For instance, sets of transcripts may be induced in response to an infectious challenge and return to baseline levels following pathogen clearance. Dynamic changes in the cellular make up of a tissue will also effect changes in transcript abundance that will be measured on a genome-wide scale.

Transcriptional profiles have been obtained from many human tissues -including, for instance, the skin [5,6], muscle [7], liver [8,9], kidney [10,11] or brain [12] - but the status of the immune system can be best monitored by profiling transcript abundance in blood. Indeed, profiling transcript abundance in blood provides a 'snap shot' of the complex immune networks that operate throughout the entire body. However, while this has proven to be a valid approach to finding clues about 
pathogenesis as well as to identifying potential biomarkers [13-16], a number of challenges and limitations exist. Data interpretation is one of them. Firstly, the volume of data generated from such studies can be overwhelming, and it is necessary to integrate information from a multitude of sources (study design, quality control data, sample information, and importantly clinical information) in order for the results to be interpretable. Secondly, the changes in transcript abundance observed in complex tissues such as blood can be caused not only by regulation of gene transcriptional activity but also by relative changes in abundance of cell populations expressing transcripts at constant levels. Thirdly, in addition to pathogenic processes, a number of factors may affect blood transcript abundance and confound the analysis. Medications and co-morbidities are two such factors that often restrict patient selection and complicate data interpretation. This review will discuss some of the strategies recently developed that will address some of these limitations.

\section{Transcriptome profiling: a technology primer}

Real-time PCR technology is currently considered the gold standard for the analysis of gene expression. However, it can be used to measure abundance of only a limited number of transcripts. Introduced over 10 years ago, DNA microarrays are now in routine use and can measure transcript abundance on a genome-wide scale. This technology relies on dense arrays of oligonucleotide probes that will capture complementary sequences present in biological samples at various concentrations. The probes can be deposited on a solid surface (printed microarrays), synthesized in situ (Affymetrix GeneChips), or bound to glass beads lodged into wells etched in the surface of a glass slide (Illumina BeadArrays). The labeled material captured by the microarray is imaged and relative abundance determined based on the strength of the signal produced by each oligonucleotide feature. It should be noted that, while they provide a means to survey transcript abundance on a genome-wide scale, the sensitivity of microarray assays is low compared to other approaches such as real-time PCR. A microarray is not a fully quantitative assay and changes in transcript abundance must be measured in reference to control samples that need to be included in each study. However, some of these limitations may be lifted by methods relying on high-throughput sequencing for the genome-wide measurement of RNA abundance [17]. Building on the legacy of the SAGE (serial analysis of gene expression) technology introduced in the 1990s, RNA sequencing (RNA-seq) [18] uses either total or fractionated RNA, for example poly $(\mathrm{A})_{+}$, as a starting point. This material is converted to a library of cDNA fragments. High throughput sequencing of such fragments yields short sequences or reads that are typically 30 to $400 \mathrm{bp}$ in length, depending on the technology platform used. For a given sample, tens of millions of such sequences will then be uniquely mapped against a reference genome. The higher the level of expression of a given gene, the higher the number of reads that will be aligned against it (Figure 3). Thus, this approach does not rely on probe design and provides several types of information, including not only transcript abundance but also transcriptome structure (splice variants), profiles of non-coding RNA species, and genetic polymorphisms. RNA-seq is expected to become sufficiently cost-effective and practical that it will eventually supersede microarray technologies.

Other technologies should be considered for the profiling of focused sets of genes. Nanostring technology can, for instance, detect the abundance of up to 500 transcripts with high sensitivity [19]. The approach is 'digital' since it counts individual RNA molecules using strings of fluorochromes as reporters to identify the different RNA species. Other technology platforms developed by, among others, Luminex, High Throughput Genomics or Fluidigm round up the offering for 'subgenome' transcript profiling.

\section{Profiling autoimmune diseases}

The field of autoimmunity has proven a fertile ground for blood transcriptional studies. Alterations in transcript abundance in the blood of patients reflect the sustained response against self-antigens and, more generally, uncontrolled inflammatory processes. Such diseases often present with recurring-remitting patterns of activity, with episodes of flaring that may be reflected by fluctuations in transcript abundance. The work has initially focused on diseases with clear systemic involvement such as systemic lupus erythematosus (SLE) [20,21]. Multiple cell types and soluble mediators, including IL10 $[22,23]$ and IFN $\gamma$ [24-26], have been proposed to be at the center of lupus pathogenesis. While some scattered evidence indicated the potential role of type I interferon in lupus, several observations did not support the hypothesis: first, not every SLE patient has detectable serum type I IFN levels [27]; second, dysregulation of type-I IFN production is not found in most murine SLE-models [28]; and third, genetic linkage and association studies had not identified candidate lupus susceptibility genes within the IFN pathway [29]. However, in one of our earliest microarray studies we demonstrated that all but one of the pediatric patients exhibited upregulation of IFNinducible genes, and the only patient lacking this signature had been in remission for over 2 years [20]. In addition, it was found that treating SLE patients with high dose IV steroids, which are used to control disease flares, results in the silencing of the IFN signature. A surprise from these initial studies was the absence of type 


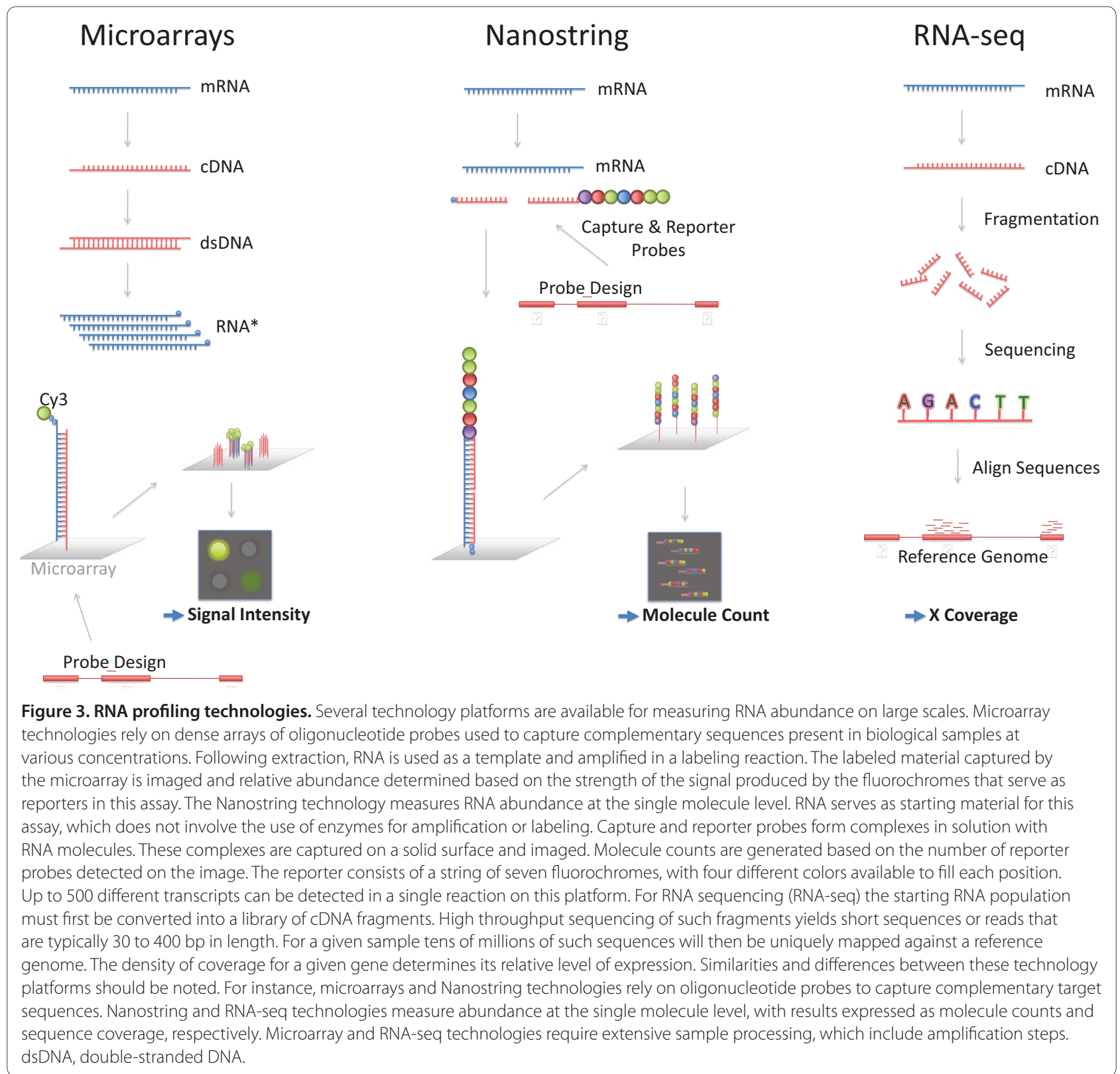

I IFN gene transcripts in the face of an abundance of IFN-inducible ones in the blood cells of SLE patients. A likely explanation is that the cells producing type I IFN, and therefore transcribing these genes, migrate to sites of injury. Altogether, results from microarray studies played a key role in convincing the community of the potential importance of type I IFN in SLE pathogenesis [15,30-34]. A phase Ia trial to evaluate the safety, pharmacokinetics, and immunogenicity of anti-IFN $\alpha$ monoclonal antibody (mAb) therapy in adult SLE patients was recently conducted [35]. The antibody elicited a specific and dosedependent inhibition of overexpression of type I IFNinducible genes in both whole blood and skin lesions from SLE patients, at both the transcript and protein levels. As expected, overexpression of BLyS/BAFF, a type I IFN-inducible gene, also decreased with treatment. Thus, this first trial supports the proposed central role of type I IFN in human SLE.

Systemic onset juvenile arthritis (SoJIA) is another disease with systemic involvement that greatly benefited from the study of blood transcriptional profiles with the development of both therapeutic and diagnostic modalities $[14,16,36,37]$. Diseases with specific organ involvement have also been the subject of significant, yet not always extensive, blood profiling efforts. Blood signatures have, for instance, been obtained from patients with 
multiple sclerosis $[38,39]$. Given the inaccessibility of the brain, blood constitutes a particularly attractive source of surrogate molecular markers for this disease. These efforts have yielded a systemic signature and identified potential predictive markers of clinical relapse and response to treatment [40-42]. Transcriptional signatures have also been generated in the context of dermatologic diseases. In this case, the target organ being readily accessible, efforts have been focusing on profiling transcript abundance in skin tissues [43,44]. However, systemic involvement has been recognized in recent years to be an important component of autoimmune skin diseases and unique blood transcriptional profiles have also been identified in patients with, for example, psoriasis [45-47].

Blood transcriptional profiles have been generated in the context of many other autoimmune diseases. Indeed, the range of autoimmune/autoinflammatory diseases that have been investigated encompasses SLE [20,21,48,49], juvenile idiopathic arthritis [16,50-53], multiple sclerosis [54,55], rheumatoid arthritis [56-59], Sjogren's syndrome [60], diabetes [61,62], inflammatory bowel disease [63], psoriasis and psoriatic arthritis [45,47], inflammatory myopathies [64,65], scleroderma [66,67], vasculitis [68] and anti-phospholipid syndrome [69]. The body of work produced that focuses on blood transcript profiling in the context of autoimmune diseases has been covered at length in a recent review [70].

\section{Profiling infectious diseases}

Global changes in transcript abundance have also been measured in the blood of patients with infectious diseases. In this context, alterations of blood transcriptional profiles are a reflection of the immunological response mounted by the host against pathogens. This response is initiated by specialized receptors expressed at the surface of host cells recognizing pathogen-associated molecular patterns [71]. Different classes of pathogens signal through different combinations of receptors, eliciting in turn different types of immune responses [72]. This translates experimentally into distinct transcriptional programs being induced upon exposure of immune cells in vitro to distinct classes of infectious agents [73-75]. Similarly, patterns of transcript abundance measured in the blood of patients with infections caused by different etiological agents were found to be distinct [13].

Predictably, dramatic changes were observed in the blood of patients with systemic infections (for example, sepsis) $[76,77]$. However, profound alterations in patterns of transcript abundance were also found in patients with localized infections (for example, upper respiratory tract infection, urinary tract infections, pulmonary tuberculosis, skin abscesses) $[13,16,78]$. Measuring changes in host transcriptional profiles may therefore prove of diagnostic value even in situations where the causative pathogenic agent is not present in the test sample. Importantly, it may also help ascertain the severity of the infection and monitor its course.

Infections often present as acute clinical events; thus, it is important to capture dynamic changes in transcript abundance that occur during the course of the infection from the time of initial exposure. Blood signatures have been described in the context of acute infections caused by a wide range of pathogenic parasites, viruses and bacteria, including Plasmodium [79,80], respiratory viruses (influenza, rhinovirus, respiratory syncytial virus) $[13,81-84]$, dengue virus [85,86], and adenovirus [82], as well as Salmonella [87], Mycobacterium tuberculosis [78], Staphylococcus aureus [88], Burkholderia pseudomallei [76] and the general context of bacterial sepsis [77,89-91]. Some of those pathogens will persist and establish chronic infections (for example, human immunodeficiency virus and Plasmodium) that may lead to a state of latency (for example, tuberculosis), and transcript profiling may be used in those situations as a surveillance tool for monitoring disease progression or reactivation.

Blood profiling of infectious diseases remains limited in scale. In particular, additional studies will be necessary to ascertain dynamic changes occurring over time.

\section{Profiling other diseases}

In addition to autoimmune and infectious diseases, blood transcript profiling studies have been carried out in the cancer research field. While hematological malignancies have led the way (reviewed in [92]), blood profiles have also been obtained more recently from patients with solid organ tumors [93]. Notably, these signatures can reflect not only the immunological or physiological changes effected by cancers but also the presence of rare tumor cells in the circulation [94-96].

Blood signatures have also been obtained from solid organ transplant recipients in the context of both tolerance [97-99] and graft rejection [10,100,101]. While such signatures can also be detected in biopsy material [102104], blood offers the distinct advantage of being accessible for safely monitoring molecular changes on a routine basis.

Some work has also been done in the context of cardiovascular diseases where inflammation is known to play an important role. Hence, profiles have been identified in a wide range of conditions, including stroke, chronic heart failure or acute coronary syndrome [105-108].

The body of published work is too large to be cited in this review - and it is likely to be only the tip of the iceberg, with a lot more unpublished data scattered throughout public and private repositories. Other efforts have yielded, for instance, blood transcriptional signatures in patients with neurodegenerative diseases 
[109-111], and those associated with disease exacerbation or responsiveness to glucocorticoids in patients with asthma [112,113], and with responses to environmental exposure [114-116], exercise $[117,118]$ or even laughter [119]. Unfortunately, too many published studies are underpowered and sometimes lack even the most rudimentary validation steps. All too often primary data are not available for reanalysis either, reflecting a lack of enforcement of editorial policies, or the absence thereof in some journals. Hence, one of the main challenges for this field is to move beyond the proof of principle stage and consolidate the wealth of data being generated.

Collectively, studies published thus far demonstrate that alterations in transcript abundance can be detected on a genome-wide scale in the blood of patients with a wide range of diseases. This statement is far from trivial given the skepticism that initially met studies investigating the blood transcriptome of patients. We have also learned that: 1) multiple diseases can share components of the blood transcriptional profile - for instance, the case for inflammation or interferon signatures; 2) while no single element of the profile may be specific to any given disease it is the combination of those elements that makes a signature unique; and finally, 3) the work accomplished to date highlights the importance of carrying out analyses aiming at directly comparing transcriptional profiles across diseases. Indeed, much can be learned, for instance, about autoimmunity from studying responses to infection, and vice versa. Furthermore, such efforts may eventually lead us closer to a molecular classification of diseases. First, however, technological and methodological advances are necessary for the blood transcriptome research field to move beyond the proof of principle stage.

\section{Moving forward}

Recent progress in blood transcriptome research has been possible thanks to the development of robust sample collection techniques and the introduction of high throughput gene expression microarray platforms. Such advances have been necessary but the margin for progression in the field is still very significant. We describe here some of the current hurdles and discuss potential solutions for overcoming them.

\section{Data management}

For years the scale of blood transcriptional studies has been constrained by the cost of the technology. With the price tag on a commercial whole genome microarray below the $\$ 100$ US mark, this is not the case anymore. Thus, data management has now become the first essential step to making large scale molecular profiling a viable proposition. Beyond storing the output of microarray instruments, data management must capture and organize information that is essential for the interpretation of the results (Figure 4). This includes sample information, data quality metrics, clinical information collected at the time of sampling, details about the experimental design, and materials and methods. Capturing such information ensures that the large volumes of data generated, which are often not published immediately, will remain exploitable for years to come. This point has become critical given the fact that results from genome-wide profiling studies can never be exploited to their fullest extent and possess considerable cumulative value when re-analyzed collectively. Notably, the results generated by other cellular and molecular profiling platforms will also need to be integrated in order to complete the picture. Therefore, implementing effective data management solutions and practices is essential to sustain the necessary increase in the scale of blood transcriptional studies (Figure 3) [120]. Unfortunately, implementing data management solutions in the laboratory is often an expensive proposition, requiring customization of off-the-shelf products or development of custom software adapted to handle specific workflows. Managing data also takes time and requires dedicated personnel. Thus, while the need is widely perceived, the commitment and steps necessary to implement effective data management solutions and practices are rarely adopted.

\section{Data mining}

A myriad of approaches have been developed for the analysis of genome-wide transcriptional profiling data [121-124]. However, there is no silver bullet when it comes to microarray data analysis. The challenges encountered are several fold: 1) dimensionality, or how to cope with the fact that the number of parameters measured exceeds by several orders of magnitude the number of conditions included in most experiments; 2) noise - a direct consequence of the first point is that results from microarray analyses are particularly permissive to noise (false discovery); 3) 'seeing' the data - data visualization is critical as it helps promote insight and supports data interpretation; 4) biological context - it is important to keep the biology in sight at all times. Indeed, while it is easy to become absorbed by the data, it is essential to use biological knowledge when designing analysis strategies. Finally, there is hardly a one-size-fits-all approach to microarray data analysis and what works in one situation may not be universally applicable. Indeed, the most common response from experts when questioned on the best way to analyze a given dataset is that 'it depends...': it depends, for instance, on the extent of the differences being observed or on the variability inherent to a given disease or study population; it depends on what questions are being asked; or it can depend on whether follow-up 


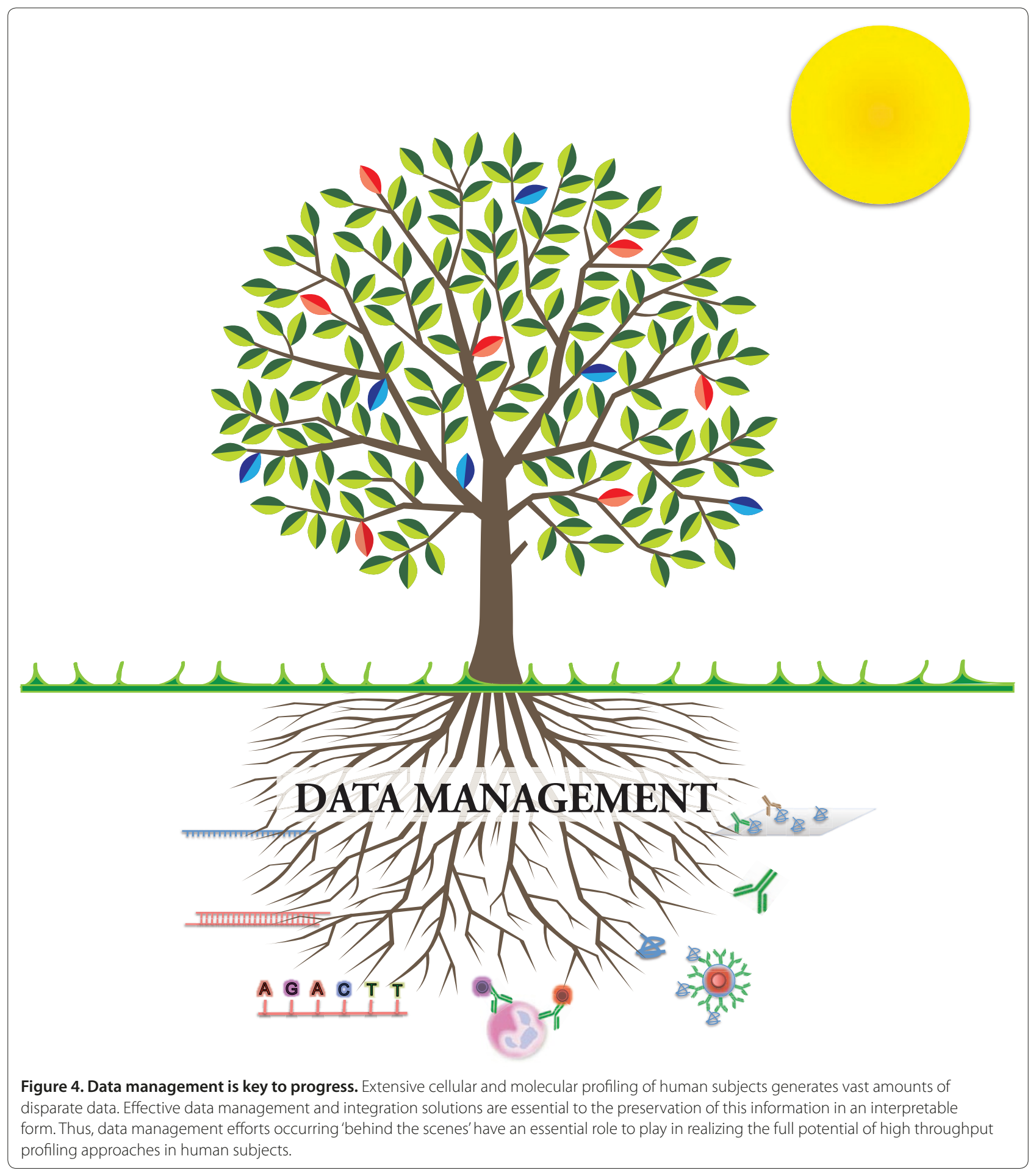

confirmatory experiments are planned. In Table 1 we provide a data mining primer that explains the basic steps involved in microarray data analysis and the considerations that arise [125-129]. Ad hoc data mining approaches can be developed to meet specific needs. For instance, we have developed a data mining strategy for the specific purpose of analyzing blood transcriptional profiles [15]. This approach simply consists of a priori grouping of sets of genes with similar transcriptional patterns. This is repeated for several different datasets and subsequently, when comparing the cluster membership of all the genes across those datasets, the genes with similar membership 
Per-chip normalization: This step controls for array-wide variations in intensity across multiple samples that form a given dataset. Arrays, as with all fluorescence based assays, are subject to signal variation for a variety of reasons, including the efficiency of the labeling and hybridization reactions and possibly other, less well defined variables, such as reagent quality and sample handling. To control for this, samples are normalized by first subtracting background and then employing a normalization algorithm to rescale the difference in overall intensity to a fixed intensity level for all samples across multiple arrays.

Data filtering: Typically more than half of the oligonucleotide probes present on a microarray do not detect a signal for any of the samples in a given analysis. Thus, a detection filter is applied to exclude these transcripts from the original dataset. This step avoids the introduction of unnecessary noise in downstream analyses.

Unsupervised analysis: The aim of this analysis is to group samples on the basis of their molecular profiles without a priori knowledge of their phenotypic classification. The first step, which functions as a second detection filter, consists of selecting transcripts that are expressed in the dataset and display some degree of variability, which will facilitate sample clustering. For instance, this filter could select transcripts with expression levels that deviate by at least two-fold from the median intensity calculated across all samples. Importantly, this additional filter is applied independently of any knowledge of sample grouping or phenotype, which makes this type of analysis 'unsupervised'. Next, pattern discovery algorithms are often applied to identify'molecular phenotypes' or trends in the data.

Clustering: Clustering is commonly used for the discovery of expression patterns in large datasets. Hierarchical clustering is an iterative agglomerative clustering method that can be used to produce gene trees and condition trees. Condition tree clustering groups samples based on the similarity of their expression profiles across a specified gene list. Other commonly employed clustering algorithms include k-means clustering and self-organizing maps.

Class comparison: Such analyses identify genes that are differentially expressed among study groups ('classes') and/or time points. The methods for analysis are chosen based on the study design. For studies with independent observations and two or more groups, $t$-tests, ANOVA, Mann-Whitney $U$ tests, or Kruskal-Wallis tests are used. Linear mixed model analyses are chosen for longitudinal studies.

Multiple testing correction: Multiple testing correction (MTC) methods provide a means to mitigate the level of noise in sets of transcripts identified by class comparison (in order to lower permissiveness of false positives). While it reduces noise, MTC promotes a higher false negative rate as a result of dampening the signal. The methods available are characterized by varying degrees of stringency, and therefore they produce gene lists with different levels of robustness.

- $\quad$ Bonferroni correction is the most stringent method used to control the familywise error rate (probability of making one or more type I errors) and can drastically reduce false positive rates. Conversely, it increases the probability of having false negatives.

- Benjamini and Hochberg false discovery rate [125] is a less stringent MTC method and provides a good balance between discovery of statistically significant genes while limiting false positives. By using this procedure with a value of $0.01,1 \%$ of the statistically significant transcripts might be identified as significant by chance alone (false positives).

Class prediction: Class prediction analyses assess the ability of gene expression data to correctly classify a study subject or sample. K-nearest neighbors is a commonly used technique for this task. Other available class prediction procedures include, but are not limited to, discriminant analysis, general linear model selection, logistic regression, distance scoring, partial least squares, partition trees, and radial basis machine.

Sample size: The number of samples necessary for the identification of a robust signature is variable. Indeed, sample size requirements will depend on the amplitude of the difference between, and the variability within, study groups.

A number of approaches have been devised for the calculation of sample size for microarray experiments, but to date little consensus exists [126-129]. Hence, best practices in the field consist of the utilization of independent sets of samples for the purpose of validating candidate signatures. Thus, the robustness of the signature identified will rely on a statistically significant association between the predicted and true phenotypic class in the first and the second test sets.

are grouped together to form what we have termed a transcriptional module. Structuring the data permits focusing downstream statistical testing on these sets of transcripts that form coherent transcriptional and functional modular units. This is in contrast with more traditional approaches that rely on iterative statistical testing for thousands of individual transcripts that are treated as independent variables. The modular transcriptional framework that we have developed reduces the number of variables by collapsing sets of coordinately expressed genes into a new entity, the module. Reducing data dimensionality as such can: 1) facilitate functional interpretation; 2) enable comparative analyses across multiple datasets and diseases; 3) minimize noise and improve robustness of biomarker signatures; and 4) yield multivariate metrics that can be used at the bedside [15]. Data visualization is also of critical importance for the interpretation of large-scale datasets. We have devised a straightforward visualization scheme for mapping global transcriptional changes for individual diseases on a modular basis (Figure 5).Briefly, differences in expression levels between study groups are displayed for each module on a grid. Each position on the grid is assigned to a given module; a red spot indicates an increase and a blue spot a decrease in transcript abundance. The spot intensity is determined by the proportion of transcripts reaching significance for a given module. A posteriori, biological interpretation has linked several modules to immune cells or pathways (see legend of Figure 5). Hence, in the example provided in Figure 5, patients with $S$. aureus infection demonstrate significant over-expression of genes in modules related to innate immunity, including myeloid (M1.5, M2.6), neutrophil (M2.2), and inflammation (M3.2, M3.3) modules, and under-expression of genes regulating adaptive immunity such as those in B cell (M1.3), cytotoxic cell (M2.1), and T-cell-specific (M2.8) 

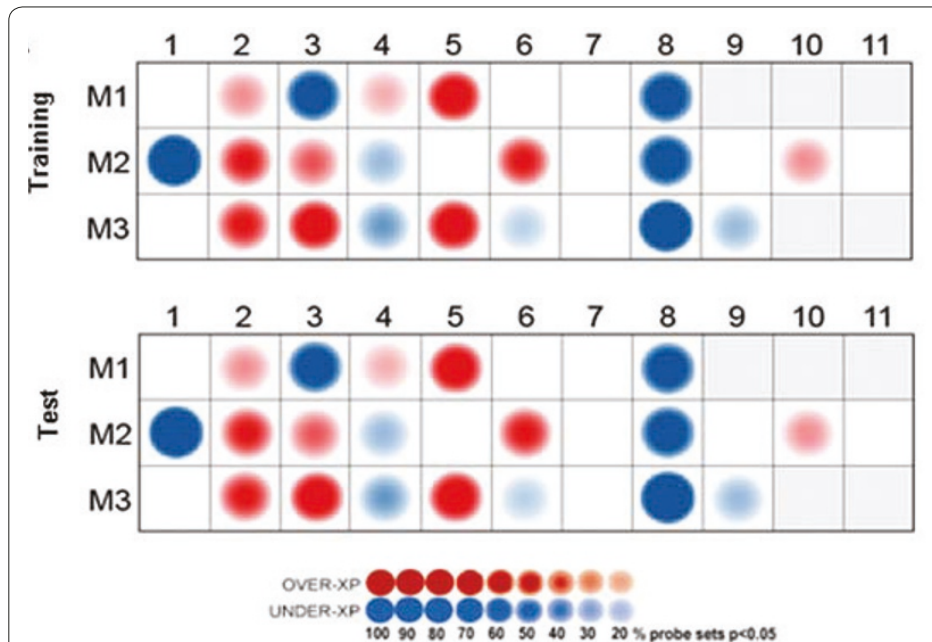

Functional Interpretation

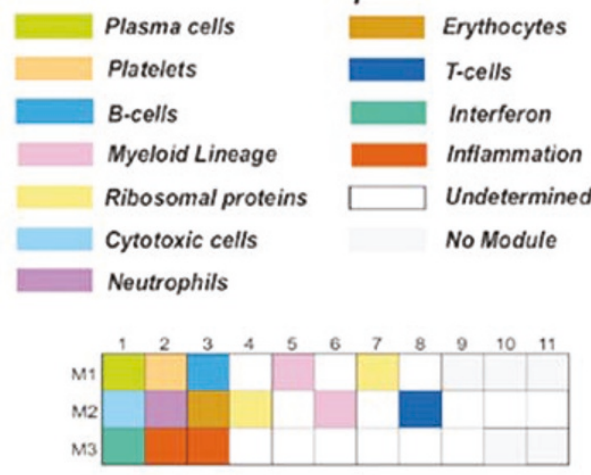

Figure 5. Blood transcriptional fingerprints of patients with Staphylococcus aureus infection. Relative changes in transcript abundance in the blood of patients with S. aureus infection compared to that of healthy controls are recorded for a set of 28 transcriptional modules. Colored spots represent relative increase (red) or decrease (blue) in transcript abundance $(P<0.05$, Mann Whitney) within a module. The legend shows functional interpretation for this set of modules. Fingerprints have been generated for two independent cohorts of subjects (divided into a training set used in the discovery phase, $n=30$, and an independent test set used in the validation phase, $n=32$ ).

modules. It should also be noted that no changes were observed for other modules, such as module M3.1, which includes interferon-inducible genes, abundance of which would be increased in the context of a viral infection.

\section{Beyond mRNA: profiling microRNAs}

MicroRNA (miRNA) control has emerged as a critical regulatory circuit of the immune system. Measuring changes in miRNA abundance in the blood of human subjects in health and disease is therefore a promising new field of investigation. These short non-coding singlestranded RNAs about 22 nucleotides in length have been found to play essential regulatory roles [130-132]. These molecules exhibit highly specific, regulated patterns of expression and control protein expression by translational repression, mRNA cleavage, or promotion of mRNA decay. Interestingly, thanks to their small size, miRNA molecules are stable and can be measured not only in blood cells but also in circulation in the serum [133]. They are thus not only potentially important contributors to immune function, but also potential sources of biomarkers.

\section{Deconvoluting blood transcriptional signatures}

Blood transcriptome research will also benefit from conceptual advances that may help address shortcomings inherent to whole blood profiling.

First, blood is a complex tissue and changes in transcript abundance can be attributed to either transcriptional regulation or relative changes in composition of leukocyte populations. Two approaches exist for 'deconvoluting' these two phenomena. First, one can isolate and individually profile different cell populations present in the blood. This approach may also permit the identification of transcripts expressed at low levels or the detection of differences in expression that would otherwise be drowned in whole blood $[134,135]$. However, isolation methods may introduce technical bias, and require extensive sample processing. A second approach consists of deconvoluting whole blood transcriptional profiles 'in silico'. This type of analysis attempts to deduce cellular composition or cell-specific levels of gene expression using statistical methodologies [136-141].

Finally, we must also keep in mind that the immune status of a human subject is not entirely reflected by its blood profile obtained at the steady state. Indeed, an individual's capacity to respond to innate as well as antigen-specific immune signals may also provide useful and complementary information.

In conclusion, blood transcript profiling has earned its place in the molecular and cellular profiling armamentarium used to study the human immune system. Changes in transcript abundance recapitulate the influence of genetic, epigenetic, cellular and environmental factors. Initially considered to belong to the 'cutting edge', this approach has become both robust and practical. As discussed in this review, it has become a mainstay for the study of immune function in patients with a wide range of diseases. Furthermore, recent studies have demonstrated the utility of blood transcriptome profiling for monitoring immune responses to drugs or vaccines $[35,142,143]$. Thus, blood transcript profiling is developing 
into a mainstream tool for the assessment of the status of the human immune system.

\section{Acknowledgements}

The work of the authors is supported by the Baylor Health Care System Foundation and the National Institutes of Health (U19 AlO57234-02, U01 Al082110, P01 CA084512)

\section{Published: 1 July 2010}

\section{References}

1. Gregersen PK, Olsson LM: Recent advances in the genetics of autoimmune disease. Annu Rev Immunol 2009, 27:363-391.

2. Zhernakova A, van Diemen CC, Wijmenga C: Detecting shared pathogenesis from the shared genetics of immune-related diseases. Nat Rev Genet 2009, 10:43-55.

3. Fellay J, Shianna KV, Ge D, Colombo S, Ledergerber B, Weale M, Zhang K, Gumbs C, Castagna A, Cozzi-Lepri A, De Luca A, Easterbrook P, Günthard HF, Mallal S, Mussini C, Dalmau J, Martinez-Picado J, Miro JM, Obel N, Wolinsky SM, Martinson JJ, Detels R, Margolick JB, Jacobson LP, Descombes P, Antonarakis SE, Beckmann JS, O'Brien SJ, et al: A whole-genome association study of major determinants for host control of HIV-1. Science 2007 317:944-947.

4. Tanaka Y, Nishida N, Sugiyama M, Kurosaki M, Matsuura K, Sakamoto N, Nakagawa M, Korenaga M, Hino K, Hige S, Ito Y, Mita E, Tanaka E, Mochida S, Murawaki Y, Honda M, Sakai A, Hiasa Y, Nishiguchi S, Koike A, Sakaida I, Imamura M, Ito K, Yano K, Masaki N, Sugauchi F, Izumi N, Tokunaga K, Mizokami M: Genome-wide association of IL28B with response to pegylated interferon-alpha and ribavirin therapy for chronic hepatitis $C$. Nat Genet 2009, 41:1105-1109.

5. Greco JA 3rd, Pollins AC, Boone BE, Levy SE, Nanney LB: A microarray analysis of temporal gene expression profiles in thermally injured human skin. Burns 2010, 36:192-204

6. Cole J, Tsou R, Wallace K, Gibran N, Isik F: Comparison of normal human skin gene expression using cDNA microarrays. Wound Repair Regen 2001 9:77-85.

7. Berchtold LA, Larsen CM, Vaag A, Faulenbach M, Workman CT, Kruhoffer M, Donath M, Mandrup-Poulsen T: IL-1 receptor antagonism and muscle gene expression in patients with type 2 diabetes. Eur Cytokine Netw 2009, 20:81-87

8. Frueh FW, Hayashibara KC, Brown PO, Whitlock JP Jr: Use of cDNA microarrays to analyze dioxin-induced changes in human liver gene expression. Toxicol Lett 2001, 122:189-203.

9. Flanagan JM, Steward S, Hankins JS, Howard TM, Neale G, Ware RE: Microarray analysis of liver gene expression in iron overloaded patients with sickle cell anemia and beta-thalassemia. Am J Hematol 2009, 84:328-334

10. Flechner SM, Kurian SM, Head SR, Sharp SM, Whisenant TC, Zhang J, Chisma JD, Horvath S, Mondala T, Gilmartin T, Cook DJ, Kay SA, Walker JR, Salomon DR: Kidney transplant rejection and tissue injury by gene profiling of biopsies and peripheral blood lymphocytes. Am J Transplant 2004, 4:1475-1489.

11. Bunnag S, Einecke G, Reeve J, Jhangri GS, Mueller TF, Sis B, Hidalgo LG, Mengel M, Kayser D, Kaplan B, Halloran PF: Molecular correlates of renal function in kidney transplant biopsies. J Am Soc Nephrol 2009, 20:1149-1160.

12. Glatt SJ, Everall IP, Kremen WS, Corbeil J, Sasik R, Khanlou N, Han M, Liew CC, Tsuang MT: Comparative gene expression analysis of blood and brain provides concurrent validation of SELENBP1 up-regulation in schizophrenia. Proc Nat/ Acad Sci U S A 2005, 102:15533-15538.

13. Ramilo O, Allman W, Chung W, Mejias A, Ardura M, Glaser C, Wittkowski KM, Piqueras B, Banchereau J, Palucka AK, Chaussabel D: Gene expression patterns in blood leukocytes discriminate patients with acute infections. Blood 2007, 109:2066-2077.

14. Pascual V, Allantaz F, Arce E, Punaro M, Banchereau J: Role of interleukin-1 (IL-1) in the pathogenesis of systemic onset juvenile idiopathic arthritis and clinical response to IL-1 blockade. J Exp Med 2005, 201:1479-1486.

15. Chaussabel D, Quinn C, Shen J, Patel P, Glaser C, Baldwin N, Stichweh D, Blankenship D, Li L, Munagala I, Bennett L, Allantaz F, Mejias A, Ardura M, Kaizer E, Monnet L, Allman W, Randall H, Johnson D, Lanier A, Punaro M,
Wittkowski KM, White P, Fay J, Klintmalm G, Ramilo O, Palucka AK, Banchereau J, Pascual V: A modular analysis framework for blood genomics studies: application to systemic lupus erythematosus. Immunity 2008, 29:150-164.

16. Allantaz F, Chaussabel D Allantaz F, Chaussabel D, Stichweh D, Bennett L, Allman W, Mejias A, Ardura M, Chung W, Smith E, Wise C, Palucka K, Ramilo O, Punaro M, Banchereau J, Pascual V: Blood leukocyte microarrays to diagnose systemic onset juvenile idiopathic arthritis and follow the response to IL-1 blockade. J Exp Med 2007, 204:2131-2144

17. Wold B, Myers RM: Sequence census methods for functional genomics. Nat Methods 2008, 5:19-21.

18. Sultan M, Schulz MH, Richard H, Magen A, Klingenhoff A, Scherf M, Seifert M, Borodina T, Soldatov A, Parkhomchuk D, Schmidt D, O'Keeffe S, Haas S, Vingron M, Lehrach $\mathrm{H}$, Yaspo ML: A global view of gene activity and alternative splicing by deep sequencing of the human transcriptome. Science 2008, 321:956-960.

19. Geiss GK, Bumgarner RE, Birditt B, Dahl T, Dowidar N, Dunaway DL, Fell HP, Ferree S, George RD, Grogan T, James JJ, Maysuria M, Mitton JD, Oliveri P, Osborn JL, Peng T, Ratcliffe AL, Webster PJ, Davidson EH, Hood L, Dimitrov K: Direct multiplexed measurement of gene expression with color-coded probe pairs. Nat Biotechnol 2008, 26:317-325

20. Bennett L, Palucka AK, Arce E, Cantrell V, Borvak J, Banchereau J, Pascual V: Interferon and granulopoiesis signatures in systemic lupus erythematosus blood. J Exp Med 2003, 197:711-723.

21. Baechler EC, Batliwalla FM, Karypis G, Gaffney PM, Ortmann WA, Espe KJ, Shark KB, Grande WJ, Hughes KM, Kapur V, Gregersen PK, Behrens TW: Interferon-inducible gene expression signature in peripheral blood cells of patients with severe lupus. Proc Natl Acad Sci U S A 2003, 100:2610-2615.

22. Llorente L, Zou W, Levy Y, Richaud-Patin Y, Wijdenes J, Alcocer-Varela J, MorelFourrier B, Brouet JC, Alarcon-Segovia D, Galanaud P, Emilie D: Role of interleukin 10 in the B lymphocyte hyperactivity and autoantibody production of human systemic lupus erythematosus. J Exp Med 1995, 181:839-844.

23. Llorente L, Richaud-Patin Y, García-Padilla C, Claret E, Jakez-Ocampo J, Cardie MH, Alcocer-Varela J, Grangeot-Keros L, Alarcón-Segovia D, Wijdenes J, Galanaud P, Emilie D: Clinical and biologic effects of anti-interleukin-10 monoclonal antibody administration in systemic lupus erythematosus. Arthritis Rheum 2000, 43:1790-1800.

24. Yokoyama H, Takabatake T, Takaeda M, Wada T, Naito T, Ikeda K, Goshima S, Takasawa K, Tomosugi N, Kobayashi K, Kida H: Up-regulated MHC-class II expression and gamma-IFN and soluble IL-2R in lupus nephritis. Kidney Int 1992, 42:755-763.

25. Haas C, Ryffel B, Le Hir M: IFN-gamma is essential for the development of autoimmune glomerulonephritis in MRL/Ipr mice. J Immuno/ 1997, 158:5484-5491.

26. Horwitz DA, Gray JD, Behrendsen SC, Kubin M, Rengaraju M, Ohtsuka K, Trinchieri G: Decreased production of interleukin-12 and other Th1-type cytokines in patients with recent-onset systemic lupus erythematosus. Arthritis Rheum 1998, 41:838-844.

27. Preble OT, Black RJ, Friedman RM, Klippel JH, Vilcek J: Systemic lupus erythematosus: presence in human serum of an unusual acid-labile leukocyte interferon. Science 1982, 216:429-431.

28. Liu K, Mohan C: What do mouse models teach us about human SLE? Clin Immunol 2006, 119:123-130

29. Tsao BP: Update on human systemic lupus erythematosus genetics. Curr Opin Rheumatol 2004, 16:513-521.

30. Sandrin-Garcia P, Junta CM, Fachin AL, Mello SS, Baião AM, Rassi DM, Ferreira MC, Trevisan GL, Sakamoto-Hojo ET, Louzada-Júnior P, Passos GA, Donadi EA Shared and unique gene expression in systemic lupus erythematosus depending on disease activity. Ann N Y Acad Sci 2009, 1173:493-500.

31. Petri M, Singh S, Tesfasyone H, Dedrick R, Fry K, Lal P, Williams G, Bauer J, Gregersen P, Behrens T, Baechler E: Longitudinal expression of type I interferon responsive genes in systemic lupus erythematosus. Lupus 2009 18:980-989.

32. Nikpour M, Dempsey AA, Urowitz MB, Gladman DD, Barnes DA: Association of a gene expression profile from whole blood with disease activity in systemic lupus erythaematosus. Ann Rheum Dis 2008, 67:1069-1075.

33. Nakou M, Knowlton N, Frank MB, Bertsias G, Osban J, Sandel CE, Papadaki H, Raptopoulou A, Sidiropoulos P, Kritikos I, Tassiulas I, Centola M, Boumpas DT: Gene expression in systemic lupus erythematosus: bone marrow analysis differentiates active from inactive disease and reveals apoptosis and granulopoiesis signatures. Arthritis Rheum 2008, 58:3541-3549. 
34. Bauer JW, Petri M, Batliwalla FM, Koeuth T, Wilson J, Slattery C, PanoskaltsisMortari A, Gregersen PK, Behrens TW, Baechler EC: Interferon-regulated chemokines as biomarkers of systemic lupus erythematosus disease activity: a validation study. Arthritis Rheum 2009, 60:3098-3107.

35. Yao Y, Richman L, Higgs BW, Morehouse CA, de los Reyes M, Brohawn P, Zhang J, White B, Coyle AJ, Kiener PA, Jallal B: Neutralization of interferonalpha/beta-inducible genes and downstream effect in a phase I trial of an anti-interferon-alpha monoclonal antibody in systemic lupus erythematosus. Arthritis Rheum 2009, 60:1785-1796.

36. Pascual V, Allantaz F, Patel P, Palucka AK, Chaussabel D, Banchereau J: How the study of children with rheumatic diseases identified interferon-alpha and interleukin-1 as novel therapeutic targets. Immunol Rev 2008, 223:39-59.

37. Allantaz F, Chaussabel D, Banchereau J, Pascual V: Microarray-based identification of novel biomarkers in IL-1-mediated diseases. Curr Opin Immunol 2007, 19:623-632.

38. Bomprezzi R, Ringnér M, Kim S, Bittner ML, Khan J, Chen Y, Elkahloun A, Yu A Bielekova B, Meltzer PS, Martin R, McFarland HF, Trent JM: Gene expression profile in multiple sclerosis patients and healthy controls: identifying pathways relevant to disease. Hum Mol Genet 2003, 12:2191-2199.

39. Achiron A, Gurevich M, Friedman N, Kaminski N, Mandel M: Blood transcriptional signatures of multiple sclerosis: unique gene expression of disease activity. Ann Neurol 2004, 55:410-417.

40. van Baarsen LG, Vosslamber S, Tijssen M, Baggen JM, van der Voort LF, Killestein J, van der Pouw Kraan TC, Polman CH, Verweij CL: Pharmacogenomics of interferon-beta therapy in multiple sclerosis: baseline IFN signature determines pharmacological differences between patients. PLoS One 2008, 3:e1927.

41. Gurevich M, Tuller T, Rubinstein U, Or-Bach R, Achiron A: Prediction of acute multiple sclerosis relapses by transcription levels of peripheral blood cells. BMC Med Genomics 2009, 2:46.

42. Achiron A, Gurevich M, Snir Y, Segal E, Mandel M: Zinc-ion binding and cytokine activity regulation pathways predicts outcome in relapsingremitting multiple sclerosis. Clin Exp Immunol 2007, 149:235-242.

43. Nomura I, Gao B, Boguniewicz M, Darst MA, Travers JB, Leung DY: Distinct patterns of gene expression in the skin lesions of atopic dermatitis and psoriasis: a gene microarray analysis. J Allergy Clin Immunol 2003, 112:1195-1202.

44. de Jongh GJ, Zeeuwen PL, Kucharekova M, Pfundt R, van der Valk PG, Blokx W, Dogan A, Hiemstra PS, van de Kerkhof PC, Schalkwijk J: High expression levels of keratinocyte antimicrobial proteins in psoriasis compared with atopic dermatitis. J Invest Dermatol 2005, 125:1163-1173.

45. Stoeckman AK, Baechler EC, Ortmann WA, Behrens TW, Michet CJ, Peterson $\mathrm{EJ}$ : A distinct inflammatory gene expression profile in patients with psoriatic arthritis. Genes Immun 2006, 7:583-591.

46. Koczan D, Guthke R, Thiesen HJ, Ibrahim SM, Kundt G, Krentz H, Gross G, Kunz $\mathrm{M}$ : Gene expression profiling of peripheral blood mononuclear leukocytes from psoriasis patients identifies new immune regulatory molecules. Eur $J$ Dermatol 2005, 15:251-257.

47. Batliwalla FM, Li W, Ritchlin CT, Xiao X, Brenner M, Laragione T, Shao T, Durham R, Kemshetti S, Schwarz E, Coe R, Kern M, Baechler EC, Behrens TW, Gregersen PK, Gulko PS: Microarray analyses of peripheral blood cells identifies unique gene expression signature in psoriatic arthritis. Mol Med 2005, 11:21-29.

48. Crow MK, Wohlgemuth J: Microarray analysis of gene expression in lupus. Arthritis Res Ther 2003, 5:279-287.

49. Han GM, Chen SL, Shen N, Ye S, Bao CD, Gu YY: Analysis of gene expression profiles in human systemic lupus erythematosus using oligonucleotide microarray. Genes Immun 2003, 4:177-186.

50. Pascual V, Allantaz F, Arce E, Punaro M, Banchereau J: Role of interleukin-1 (IL-1) in the pathogenesis of systemic onset juvenile idiopathic arthritis and clinical response to IL-1 blockade. J Exp Med 2005, 201:1349-1350.

51. Ogilvie EM, Khan A, Hubank M, Kellam P, Woo P: Specific gene expression profiles in systemic juvenile idiopathic arthritis. Arthritis Rheum 2007, 56:1954-1965.

52. Fall N, Barnes M, Thornton S, Luyrink L, Olson J, Ilowite NT, Gottlieb BS, Griffin T, Sherry DD, Thompson S, Glass DN, Colbert RA, Grom AA: Gene expression profiling of peripheral blood from patients with untreated new-onset systemic juvenile idiopathic arthritis reveals molecular heterogeneity that may predict macrophage activation syndrome. Arthritis Rheum 2007, 56:3793-3804

53. Barnes MG, Grom AA, Thompson SD, Griffin TA, Pavlidis $P$, Itert L, Fall N,
Sowders DP, Hinze CH, Aronow BJ, Luyrink LK, Srivastava S, llowite NT, Gottlieb BS, Olson JC, Sherry DD, Glass DN, Colbert RA.: Subtype-specific peripheral blood gene expression profiles in recent-onset juvenile idiopathic arthritis. Arthritis Rheum 2009, 60:2102-2112.

54. Achiron A, Feldman A, Mandel M, Gurevich M: Impaired expression of peripheral blood apoptotic-related gene transcripts in acute multiple sclerosis relapse. Ann N Y Acad Sci 2007, 1107:155-167.

55. Singh MK, Scott TF, LaFramboise WA, Hu FZ, Post JC, Ehrlich GD: Gene expression changes in peripheral blood mononuclear cells from multiple sclerosis patients undergoing beta-interferon therapy. J Neurol Sci 2007, 258:52-59.

56. Edwards CJ, Feldman JL, Beech J, Shields KM, Stover JA, Trepicchio WL, Larsen G, Foxwell BM, Brennan FM, Feldmann M, Pittman DD: Molecular profile of peripheral blood mononuclear cells from patients with rheumatoid arthritis. Mol Med 2007, 13:40-58.

57. van der Pouw Kraan TC, Wijbrandts CA, van Baarsen LG, Voskuyl AE, Rustenburg F, Baggen JM, Ibrahim SM, Fero M, Dijkmans BA, Tak PP, Verweij $\mathrm{CL}$ : Rheumatoid arthritis subtypes identified by genomic profiling of peripheral blood cells: assignment of a type I interferon signature in a subpopulation of patients. Ann Rheum Dis 2007, 66:1008-1014.

58. Lequerré T, Gauthier-Jauneau AC, Bansard C, Derambure C, Hiron M, Vittecoq O, Daveau M, Mejjad O, Daragon A, Tron F, Le Loët X, Salier JP: Gene profiling in white blood cells predicts infliximab responsiveness in rheumatoid arthritis. Arthritis Res Ther 2006, 8:R105.

59. Batliwalla FM, Baechler EC, Xiao X, Li W, Balasubramanian S, Khalili H, Damle A, Ortmann WA, Perrone A, Kantor AB, Gulko PS, Kern M, Furie R, Behrens TW, Gregersen PK: Peripheral blood gene expression profiling in rheumatoid arthritis. Genes Immun 2005, 6:388-397.

60. Emamian ES, Leon JM, Lessard CJ, Grandits M, Baechler EC, Gaffney PM, Segal B, Rhodus NL, Moser KL: Peripheral blood gene expression profiling in Sjogren's syndrome. Genes Immun 2009, 10:285-296.

61. Kaizer EC, Glaser CL, Chaussabel D, Banchereau J, Pascual V, White PC: Gene expression in peripheral blood mononuclear cells from children with diabetes. J Clin Endocrinol Metab 2007, 92:3705-3711.

62. Takamura T, Honda M, Sakai Y, Ando H, Shimizu A, Ota T, Sakurai M, Misu H, Kurita S, Matsuzawa-Nagata N, Uchikata M, Nakamura S, Matoba R, Tanino M, Matsubara K, Kaneko S: Gene expression profiles in peripheral blood mononuclear cells reflect the pathophysiology of type 2 diabetes. Biochem Biophys Res Commun 2007, 361:379-384.

63. Burczynski ME, Peterson RL, Twine NC, Zuberek KA, Brodeur BJ, Casciotti L, Maganti V, Reddy PS, Strahs A, Immermann F, Spinelli W, Schwertschlag U, Slager AM, Cotreau MM, Dorner AJ: Molecular classification of Crohn's disease and ulcerative colitis patients using transcriptional profiles in peripheral blood mononuclear cells. J Mol Diagn 2006, 8:51-61.

64. Greenberg SA, Pinkus JL, Pinkus GS, Burleson T, Sanoudou D, Tawil R, Barohn RJ, Saperstein DS, Briemberg HR, Ericsson M, Park P, Amato AA: Interferonalpha/beta-mediated innate immune mechanisms in dermatomyositis. Ann Neurol 2005, 57:664-678.

65. Baechler EC, Bauer JW, Slattery CA, Ortmann WA, Espe KJ, Novitzke J, Ytterberg SR, Gregersen PK, Behrens TW, Reed AM: An interferon signature in the peripheral blood of dermatomyositis patients is associated with disease activity. Mol Med 2007, 13:59-68.

66. Tan FK, Zhou X, Mayes MD, Gourh P, Guo X, Marcum C, Jin L, Arnett FC Jr: Signatures of differentially regulated interferon gene expression and vasculotrophism in the peripheral blood cells of systemic sclerosis patients. Rheumatology 2006, 45:694-702.

67. York MR, Nagai T, Mangini AJ, Lemaire R, van Seventer JM, Lafyatis R: A macrophage marker, Siglec-1, is increased on circulating monocytes in patients with systemic sclerosis and induced by type I interferons and toll-like receptor agonists. Arthritis Rheum 2007, 56:1010-1020.

68. Alcorta DA, Barnes DA, Dooley MA, Sullivan P, Jonas B, Liu Y, Lionaki S, Reddy CB, Chin H, Dempsey AA, Jennette JC, Falk RJ: Leukocyte gene expression signatures in antineutrophil cytoplasmic autoantibody and lupus glomerulonephritis. Kidney Int 2007, 72:853-864.

69. Potti A, Bild A, Dressman HK, Lewis DA, Nevins JR, Ortel TL: Gene-expression patterns predict phenotypes of immune-mediated thrombosis. Blood 2006, 107:1391-1396.

70. Pascual V, Chaussabel D, Banchereau J: A genomic approach to human autoimmune diseases. Annu Rev Immunol 2010, 28:535-571.

71. Janeway CA Jr, Medzhitov R: Innate immune recognition. Annu Rev Immunol 2002, 20:197-216. 
72. Aderem A, Ulevitch RJ: Toll-like receptors in the induction of the innate immune response. Nature 2000, 406:782-787.

73. Nau GJ, Richmond JF, Schlesinger A, Jennings EG, Lander ES, Young RA: Human macrophage activation programs induced by bacterial pathogens. Proc Natl Acad Sci U S A 2002, 99:1503-1508.

74. Huang Q, Liu D, Majewski P, Schulte LC, Korn JM, Young RA, Lander ES, Hacohen N: The plasticity of dendritic cell responses to pathogens and their components. Science 2001, 294:870-875.

75. Chaussabel D, Semnani RT, McDowell MA, Sacks D, Sher A, Nutman TB: Unique gene expression profiles of human macrophages and dendritic cells to phylogenetically distinct parasites. Blood 2003, 102:672-681.

76. Pankla R, Buddhisa S, Berry M, Blankenship DM, Bancroft GJ, Banchereau J, Lertmemongkolchai G, Chaussabel D: Genomic transcriptional profiling identifies a candidate blood biomarker signature for the diagnosis of septicemic melioidosis. Genome Bio/ 2009, 10:R127.

77. Tang BM, McLean AS, Dawes IW, Huang SJ, Lin RC: Gene-expression profiling of peripheral blood mononuclear cells in sepsis. Crit Care Med 2009, 37:882-888.

78. Jacobsen M, Repsilber D, Gutschmidt A, Neher A, Feldmann K, Mollenkopf HJ, Ziegler A, Kaufmann SH: Candidate biomarkers for discrimination between infection and disease caused by Mycobacterium tuberculosis. J Mol Med 2007, 85:613-621.

79. Griffiths MJ, Shafi MJ, Popper SJ, Hemingway CA, Kortok MM, Wathen A, Rockett KA, Mott R, Levin M, Newton CR, Marsh K, Relman DA, Kwiatkowski DP: Genomewide analysis of the host response to malaria in Kenyan children. J Infect Dis 2005, 191:1599-1611.

80. Franklin BS, Parroche P, Ataíde MA, Lauw F, Ropert C, de Oliveira RB, Pereira D, Tada MS, Nogueira P, da Silva LH, Bjorkbacka H, Golenbock DT, Gazzinelli RT: Malaria primes the innate immune response due to interferon-gamma induced enhancement of toll-like receptor expression and function. Proc Natl Acad SciU S A 2009, 106:5789-5794.

81. Reghunathan R, Jayapal M, Hsu LY, Chng HH, Tai D, Leung BP, Melendez AJ: Expression profile of immune response genes in patients with severe acute respiratory syndrome. BMC Immunol 2005, 6:2.

82. Popper SJ, Watson VE, Shimizu C, Kanegaye JT, Burns JC, Relman DA: Gene transcript abundance profiles distinguish Kawasaki disease from adenovirus infection. J Infect Dis 2009, 200:657-666.

83. Zaas AK, Chen M, Varkey J, Veldman T, Hero AO 3rd, Lucas J, Huang Y, Turner R, Gilbert A, Lambkin-Williams R, Øien NC, Nicholson B, Kingsmore S, Carin L, Woods CW, Ginsburg GS: Gene expression signatures diagnose influenza and other symptomatic respiratory viral infections in humans. Cell Host Microbe 2009 , 6:207-217.

84. Thach DC, Agan BK, Olsen C, Diao J, Lin B, Gomez J, Jesse M, Jenkins M, Rowley R, Hanson E, Tibbetts C, Stenger DA, Walter E; Epidemic Outbreak Surveillance (EOS): Surveillance of transcriptomes in basic military trainees with normal, febrile respiratory illness, and convalescent phenotypes. Genes Immun 2005, 6:588-595.

85. Ubol S, Masrinoul P, Chaijaruwanich J, Kalayanarooj S, CharoensirisuthikulT, Kasisith J: Differences in global gene expression in peripheral blood mononuclear cells indicate a significant role of the innate responses in progression of dengue fever but not dengue hemorrhagic fever. J Infect Dis 2008, 197:1459-1467.

86. Nascimento EJ, Braga-Neto U, Calzavara-Silva CE, Gomes AL, Abath FG, Brito CA, Cordeiro MT, Silva AM, Magalhães C, Andrade R, Gil LH, Marques ET Jr: Gene expression profiling during early acute febrile stage of dengue infection can predict the disease outcome. PLoS One 2009, 4:e7892.

87. Thompson LJ, Dunstan SJ, Dolecek C, Perkins T, House D, Dougan G, Nguyen TH, Tran TP, Doan CD, Le TP, Nguyen TD, Tran TH, Farrar JJ, Monack D, Lynn DJ, Popper SJ, Falkow S: Transcriptional response in the peripheral blood of patients infected with Salmonella enterica serovar Typhi. Proc Natl Acad Sci USA 2009, 106:22433-22438.

88. Ardura MI, Banchereau R, Mejias A, Di Pucchio T, Glaser C, Allantaz F, Pascual V, Banchereau J, Chaussabel D, Ramilo O: Enhanced monocyte response and decreased central memory T cells in children with invasive Staphylococcus aureus infections. PLoS One 2009, 4:e5446.

89. Wong HR, Cvijanovich N, Allen GL, Lin R, Anas N, Meyer K, Freishtat RJ, Monaco M, Odoms K, Sakthivel B, Shanley TP; Genomics of Pediatric SIRS/ Septic Shock Investigators: Genomic expression profiling across the pediatric systemic inflammatory response syndrome, sepsis, and septic shock spectrum. Crit Care Med 2009, 37:1558-1566

90. Payen D, Lukaszewicz AC, Belikova I, Faivre V, Gelin C, Russwurm S, Launay JM,
Sevenet N: Gene profiling in human blood leucocytes during recovery from septic shock. Intensive Care Med 2008, 34:1371-1376.

91. Johnson SB, Lissauer M, Bochicchio GV, Moore R, Cross AS, Scalea TM: Gene expression profiles differentiate between sterile SIRS and early sepsis. Ann Surg 2007, 245:611-621.

92. Staratschek-Jox A, Classen S, Gaarz A, Debey-Pascher S, Schultze JL: Bloodbased transcriptomics: leukemias and beyond. Expert Rev Mol Diagn 2009, 9:271-280.

93. Aaroe J, Lindahl T, Dumeaux V, Saebo S, Tobin D, Hagen N, Skaane $P$ Lonneborg A, Sharma P, Borresen-Dale AL: Gene expression profiling of peripheral blood cells for early detection of breast cancer. Breast Cancer Res 2010, 12:R7.

94. Findeisen P, Rockel M, Nees M, Roder C, Kienle P, Von Knebel Doeberitz M, Kalthoff H, Neumaier M: Systematic identification and validation of candidate genes for detection of circulating tumor cells in peripheral blood specimens of colorectal cancer patients. Int J Oncol 2008, 33:1001-1010

95. Hayes DC, Secrist H, Bangur CS, Wang T, Zhang X, Harlan D, Goodman GE, Houghton RL, Persing DH, Zehentner BK: Multigene real-time PCR detection of circulating tumor cells in peripheral blood of lung cancer patients. Anticancer Res 2006, 26:1567-1575

96. Martin KJ, Graner E, Li Y, Price LM, Kritzman BM, Fournier MV, Rhei E, Pardee $A B$ : High-sensitivity array analysis of gene expression for the early detection of disseminated breast tumor cells in peripheral blood. Proc Natl Acad Sci U S A 2001, 98:2646-2651.

97. Martínez-Llordella M, Lozano JJ, Puig-Pey I, Orlando G, Tisone G, Lerut J, Benítez C, Pons JA, Parrilla P, Ramírez P, Bruguera M, Rimola A, Sánchez-Fueyo A: Using transcriptional profiling to develop a diagnostic test of operational tolerance in liver transplant recipients. J Clin Invest 2008, 118:2845-2857.

98. Kawasaki M, Iwasaki M, Koshiba T, Fujino M, Hara Y, Kitazawa Y, Kimura H, Uemoto S, Li XK, Tanaka K: Gene expression profile analysis of the peripheral blood mononuclear cells from tolerant living-donor liver transplant recipients. Int Surg 2007, 92:276-286.

99. Brouard S, Mansfield E, Braud C, Li L, Giral M, Hsieh SC, Baeten D, Zhang M, Ashton-Chess J, Braudeau C, Hsieh F, Dupont A, Pallier A, Moreau A, Louis S, Ruiz C, Salvatierra O, Soulillou JP, Sarwal M: Identification of a peripheral blood transcriptional biomarker panel associated with operational renal allograft tolerance. Proc Natl Acad Sci U S A 2007, 104:15448-15453.

100. Lin D, Hollander Z, Ng RT, Imai C, Ignaszewski A, Balshaw R, Freue GC, WilsonMcManus JE, Qasimi P, Meredith A, Mui A, Triche T, McMaster R, Keown PA, MCManus BM; Biomarkers in Transplantation Team; NCE CECR Centre of Excellence for the Prevention of Organ Failure: Whole blood genomic biomarkers of acute cardiac allograft rejection. J Heart Lung Transplant 2009, 28:927-935.

101. Alakulppi N, Seikku P, Jaatinen T, Holmberg C, Laine J: Feasibility of diagnosing subclinical renal allograft rejection in children by whole blood gene expression analysis. Transplantation 2008, 86:1222-1228.

102. Mueller TF, Einecke G, Reeve J, Sis B, Mengel M, Jhangri GS, Bunnag S, Cruz J, Wishart D, Meng C, Broderick G, Kaplan B, Halloran PF: Microarray analysis of rejection in human kidney transplants using pathogenesis-based transcript sets. Am J Transplant 2007, 7:2712-2722.

103. Sarwal M, Chua MS, Kambham N, Hsieh SC, Satterwhite T, Masek M, Salvatierra O Jr: Molecular heterogeneity in acute renal allograft rejection identified by DNA microarray profiling. N Engl J Med 2003, 349:125-138.

104. Scherer A, Krause A, Walker JR, Korn A, Niese D, Raulf F: Early prognosis of the development of renal chronic allograft rejection by gene expression profiling of human protocol biopsies. Transplantation 2003, 75:1323-1330.

105. Tang Y, Lu A, Aronow BJ, Sharp FR: Blood genomic responses differ after stroke, seizures, hypoglycemia, and hypoxia: blood genomic fingerprints of disease. Ann Neurol 2001, 50:699-707.

106. Nakayama M, Kudoh T, Kaikita K, Yoshimura M, Oshima S, Miyamoto Y, Takeya $\mathrm{M}$, Ogawa H: Class A macrophage scavenger receptor gene expression levels in peripheral blood mononuclear cells specifically increase in patients with acute coronary syndrome. Atherosclerosis 2008, 198:426-433.

107. Moore DF, Li H, Jeffries N, Wright V, Cooper RA Jr, Elkahloun A, Gelderman MP, Zudaire E, Blevins G, Yu H, Goldin E, Baird AE: Using peripheral blood mononuclear cells to determine a gene expression profile of acute ischemic stroke: a pilot investigation. Circulation 2005, 111:212-221.

108. Cappuzzello C, Napolitano M, Arcelli D, Melillo G, Melchionna R, Di Vito L, Carlini D, Silvestri L, Brugaletta S, Liuzzo G, Crea F, Capogrossi MC: Gene 
expression profiles in peripheral blood mononuclear cells of chronic heart failure patients. Physiol Genomics 2009, 38:233-240.

109. Maes OC, Xu S, Yu B, Chertkow HM, Wang E, Schipper HM: Transcriptional profiling of Alzheimer blood mononuclear cells by microarray. Neurobiol Aging 2007, 28:1795-1809.

110. Lovrecic L, Kastrin A, Kobal J, Pirtosek Z, Krainc D, Peterlin B: Gene expression changes in blood as a putative biomarker for Huntington's disease. Mov Disord 2009, 24:2277-2281

111. Borovecki F, Lovrecic L, Zhou J, Jeong H, Then F, Rosas HD, Hersch SM Hogarth P, Bouzou B, Jensen RV, Krainc D: Genome-wide expression profiling of human blood reveals biomarkers for Huntington's disease. Proc Natl Acad Sci U S A 2005, 102:11023-11028.

112. Hakonarson H, Bjornsdottir US, Halapi E, Bradfield J, Zink F, Mouy M, Helgadottir H, Gudmundsdottir AS, Andrason H, Adalsteinsdottir AE, Kristjansson K, Birkisson I, Arnason T, Andresdottir M, Gislason D, Gislason T, Gulcher JR, Stefansson K: Profiling of genes expressed in peripheral blood mononuclear cells predicts glucocorticoid sensitivity in asthma patients. Proc Natl Acad Sci U S A 2005, 102:14789-14794.

113. Aoki T, Matsumoto Y, Hirata K, Ochiai K, Okada M, Ichikawa K, Shibasaki M, Arinami T, Sumazaki R, Noguchi E: Expression profiling of genes related to asthma exacerbations. Clin Exp Allergy 2009, 39:213-221.

114. Peretz A, Peck EC, Bammler TK, Beyer RP, Sullivan JH, Trenga CA, Srinouanprachnah S, Farin FM, Kaufman JD: Diesel exhaust inhalation and assessment of peripheral blood mononuclear cell gene transcription effects: an exploratory study of healthy human volunteers. Inhal Toxicol 2007, 19:1107-1119.

115. McHale CM, Zhang L, Lan Q, Li G, Hubbard AE, Forrest MS, Vermeulen R, Chen J, Shen M, Rappaport SM, Yin S, Smith MT, Rothman N: Changes in the peripheral blood transcriptome associated with occupational benzene exposure identified by cross-comparison on two microarray platforms. Genomics 2009, 93:343-349.

116. Bushel PR, Heinloth AN, Li J, Huang L, Chou JW, Boorman GA, Malarkey DE, Houle CD, Ward SM, Wilson RE, Fannin RD, Russo MW, Watkins PB, Tennant RW, Paules RS: Blood gene expression signatures predict exposure levels. Proc Natl Acad SciU S A 2007, 104:18211-18216.

117. Kawai T, Morita K, Masuda K, Nishida K, Sekiyama A, Teshima-Kondo S, Nakaya Y, Ohta M, Saito T, Rokutan K: Physical exercise-associated gene expression signatures in peripheral blood. Clin J Sport Med 2007, 17:375-383.

118. Connolly PH, Caiozzo VJ, Zaldivar F, Nemet D, Larson J, Hung SP, Heck JD, Hatfield GW, Cooper DM: Effects of exercise on gene expression in human peripheral blood mononuclear cells. J Appl Physiol 2004, 97:1461-1469.

119. Hayashi T, Tsujii S, Iburi T, Tamanaha T, Yamagami K, Ishibashi R, Hori M, Sakamoto S, Ishii H, Murakami K: Laughter up-regulates the genes related to NK cell activity in diabetes. Biomed Res 2007, 28:281-285.

120. Chaussabel D, Ueno H, Banchereau J, Quinn C: Data management: it starts at the bench. Nat Immunol 2009, 10:1225-1227.

121. Mootha VK, Bunkenborg J, Olsen JV, Hjerrild M, Wisniewski JR, Stahl E, Bolouri MS, Ray HN, Sihag S, Kamal M, Patterson N, Lander ES, Mann M: Integrated analysis of protein composition, tissue diversity, and gene regulation in mouse mitochondria. Cell 2003, 115:629-640.

122. Segal E, Yelensky R, Koller D: Genome-wide discovery of transcriptional modules from DNA sequence and gene expression. Bioinformatics 2003 , 19 Suppl 1:i273-282

123. Allison DB, Cui X, Page GP, Sabripour M: Microarray data analysis: from disarray to consolidation and consensus. Nat Rev Genet 2006, 7:55-65.

124. Horvath S, Dong J: Geometric interpretation of gene coexpression network analysis. PLoS Comput Biol 2008, 4:e1000117.

125. Benjamini Y, Hochberg Y: Controlling the false discovery rate: a practical and powerful approach to multiple testing. J R Stat Soc Ser B 1995, 57:289-300.

126. Dobbin KK, Zhao Y, Simon RM: How large a training set is needed to develop a classifier for microarray data? Clin Cancer Res 2008, 14:108-114

127. Jorstad TS, Midelfart $\mathrm{H}$, Bones AM: A mixture model approach to sample size estimation in two-sample comparative microarray experiments. BMC Bioinformatics 2008, 9:117.

128. Pawitan Y, Michiels S, Koscielny S, Gusnanto A, Ploner A: False discovery rate, sensitivity and sample size for microarray studies. Bioinformatics 2005 , 21:3017-3024

129. Yang MC, Yang JJ, McIndoe RA, She JX: Microarray experimental design: power and sample size considerations. Physiol Genomics 2003, 16:24-28.

130. Ambros V: The functions of animal microRNAs. Nature 2004, 431:350-355.

131. Bartel DP: MicroRNAs: genomics, biogenesis, mechanism, and function. Cell 2004, 116:281-297.

132. Bushati N, Cohen SM: microRNA functions. Annu Rev Cell Dev Biol 2007, 23:175-205.

133. Cortez MA, Calin GA: MicroRNA identification in plasma and serum: a new tool to diagnose and monitor diseases. Expert Opin Biol Ther 2009, 9:703-711.

134. Haining WN, Ebert BL, Subrmanian A, Wherry EJ, Eichbaum Q, Evans JW, Mak R, Rivoli S, Pretz J, Angelosanto J, Smutko JS, Walker BD, Kaech SM, Ahmed R, Nadler LM, Golub TR: Identification of an evolutionarily conserved transcriptional signature of CD8 memory differentiation that is shared by T and B cells. J Immuno/ 2008, 181:1859-1868.

135. Baron C, Somogyi R, Greller LD, Rineau V, Wilkinson P, Cho CR, Cameron MJ, Kelvin DJ, Chagnon P, Roy DC, Busque L, Sékaly RP, Perreault C: Prediction of graft-versus-host disease in humans by donor gene-expression profiling. PLoS Med 2007, 4:e23.

136. Wang M, Master SR, Chodosh LA: Computational expression deconvolution in a complex mammalian organ. BMC Bioinformatics 2006, 7:328.

137. Lu P, Nakorchevskiy A, Marcotte EM: Expression deconvolution: a reinterpretation of DNA microarray data reveals dynamic changes in cell populations. Proc Natl Acad Sci U S A 2003, 100:10370-10375.

138. Lahdesmaki H, Shmulevich L, Dunmire V, Yli-Harja O, Zhang W: In silico microdissection of microarray data from heterogeneous cell populations. BMC Bioinformatics 2005, 6:54.

139. Abbas AR, Wolslegel K, Seshasayee D, Modrusan Z, Clark HF: Deconvolution of blood microarray data identifies cellular activation patterns in systemic lupus erythematosus. PLoS One 2009, 4:e6098.

140. Repsilber D, Kern S, Telaar A, Walz G, Black GF, Selbig J, Parida SK, Kaufmann $\mathrm{SH}$, Jacobsen M: Biomarker discovery in heterogeneous tissue samples taking the in-silico deconfounding approach. BMC Bioinformatics, 11:27.

141. Shen-Orr SS, Tibshirani R, Khatri P, Bodian DL, Staedtler F, Perry NM, Hastie T, Sarwal MM, Davis MM, Butte AJ: Cell type-specific gene expression differences in complex tissues. Nat Methods 2010, 7:287-289.

142. Gaucher D, Therrien R, Kettaf N, Angermann BR, Boucher G, Filali-Mouhim A, Moser JM, Mehta RS, Drake DR 3rd, Castro E, Akondy R, Rinfret A, Yassine-Diab B, Said EA, Chouikh Y, Cameron MJ, Clum R, Kelvin D, Somogyi R, Greller LD, Balderas RS, Wilkinson P, Pantaleo G, Tartaglia J, Haddad EK, Sékaly RP: Yellow fever vaccine induces integrated multilineage and polyfunctional immune responses. J Exp Med 2008, 205:3119-3131.

143. Querec TD, Akondy RS, Lee EK, Cao W, Nakaya HI, Teuwen D, Pirani A, Gernert K, Deng J, Marzolf B, Kennedy K, Wu H, Bennouna S, Oluoch H, Miller J, Vencio RZ, Mulligan M, Aderem A, Ahmed R, Pulendran B: Systems biology approach predicts immunogenicity of the yellow fever vaccine in humans. Nat Immunol 2009, 10:116-125.

doi:10.1186/1741-7007-8-84

Cite this article as: Chaussabel D, et al:: Assessing the human immune system through blood transcriptomics. BMC Biology 2010, 8:84. 